\title{
Modal Psikologis dan Persepsi Dukungan Organisasi terhadap Kesiapan Individu untuk Berubah pada Pegawai PPPKP-KKP
}

\author{
Fadiah Adlina, Endro Puspo Wiroko, FD Wara Timur Hayuwardhani \\ Universitas Pancasila, Jalan Raya Lenteng Agung Timur No. 56-80 Jakarta Selatan \\ email: fadiahadlina@yahoo.com
}

\begin{abstract}
This study aimed to determine the effect of psychological capital and perception of organizational support for individual readiness to change among employees. This study used correlational (nonexperimental) method. By using disproportionate stratified random sampling, there were 62 participants in Center of Marine and Fisheries at the Ministry of Marine Affairs and Fisheries. The measuring tools used in this study were Readiness for Change Scale (RFC), Psychological Capital Questionaire (PCQ), and Survey of Perceived Organizational Support (SPOS) which all of them have been adapted into Bahasa Indonesia. Data analysis technique used in this research was multiple linear regression. Results of this study indicated that psychological capital and perception of organizational support simultaneously can give significant effect to individual readiness to change.
\end{abstract}

Keywords: psychological capital, perceived organizational support, individual readiness for change

\begin{abstract}
Abstrak
Penelitian ini bertujuan untuk mengetahui pengaruh modal psikologis dan persepsi dukungan organisasi terhadap kesiapan individu untuk berubah pada pegawai. Penelitian ini menggunakan metode korelasional (non-eksperimental). Teknik sampling dengan menggunakan disproportionate stratified random sampling, didapatkan partisipan sebanyak 62 orang yang berada pada Pusat Pelatihan dan Penyuluhan Kelautan dan Perikanan Kementerian KP. Adapun alat ukur yang digunakan adalah Readiness for Change Scale (RFC), Psychological Capital Questionaire (PCQ), dan Survey of Perceived Organizational Support (SPOS) yang ketiganya sudah diadaptasi ke dalam Bahasa Indonesia. Data dianalisa dengan menggunakan teknik regresi linear berganda. Hasil penelitian menunjukkan bahwa modal psikologis dan persepsi dukungan organisasi secara bersama-sama memberikan pengaruh yang signifikan terhadap kesiapan individu untuk berubah.
\end{abstract}

Kata Kunci: modal psikologis, persepsi dukungan organisasi, kesiapan individu untuk berubah

\section{Pendahuluan}

Lingkungan yang semakin dinamis menjadikan organisasi terus dihadapkan pada kebutuhan untuk menerapkan perubahan dalam segi strategi, struktur, proses, dan budayanya (Armenakis, Harris, \& Mossholder, 1993). Oleh karena itu, organisasi dituntut untuk dapat menyesuaikan diri dengan cara melakukan perubahan (Robbins \& Judge, 2013).

Organisasi selalu melakukan perubahan agar dapat terus bertahan, sehingga perubahan bukanlah menjadi suatu pilihan namun menjadi suatu keharusan (Damarwati, 2007). Perubahan yang dilakukan suatu organisasi secara bertahap dan terus menerus dapat menyebabkan kinerja mereka maju dengan pesat, sehingga mampu mencapai sebuah kesuksesan dalam organisasi (Pramadani, 2012).

Cummings dan Worley (2008) mengemukakan bahwa perubahan organisasi berkaitan dengan konsep perubahan yang direncanakan dan cenderung berfokus pada bagaimana perubahan dapat diimplementasikan dalam organisasi. Tidak hanya pada perusahaan swasta maupun BUMN, perubahan juga dapat terjadi di kalangan Instansi Pemerintahan.

Widiatmanti (2015) menjelaskan bahwa agar perubahan benar-benar bermakna dan berkesinambungan, maka perlu mela- 
kukan revolusi mental, terutama revolusi mental birokrasi sebagai motor penggeraknya. Birokrasi merupakan ujung tombak pelaksana pemerintahan dan kunci keberhasilan dalam pembangunan karena, birokrasi secara langsung berhadapan dengan masyarakat dan perpanjangan tangan pemerintah.

Bentuk reformasi birokrasi di negara berkembang dilakukan melalui dua strategi yaitu, merevitalisasi kedudukan, peran dan fungsi kelembagaan yang menjadi motor penggerak reformasi administrasi, dan menata kembali sistem administrasi negara baik dalam hal struktur, proses, sumber daya manusia, serta relasi antar negara dan masyarakat (Desiana, 2014).

Ada beberapa faktor, yang berkontribusi terhadap efektivitas perubahan organisasi yang akan diterapkan. Salah satu faktor yang berperan penting dalam perubahan organisasi yaitu individu dalam organisasi itu sendiri atau para pegawainya, dikarenakan organisasi terdiri dari beberapa individu yang bekerja sama untuk mencapai suatu tujuan organisasi (Robbins \& Judge, 2013). Penting bagi suatu organisasi yang akan melakukan perubahan untuk mendapat dukungan dari pegawai yang terbuka untuk mempersiapkan diri dengan baik dan siap untuk berubah (Eby, Adams, Russell, \& Gaby, 2000).

Pegawai yang kurang memiliki kesiapan untuk berubah memandang perubahan sebagai suatu hal yang tidak diinginkan dan dihindari, bahkan menolak untuk ikut berpartisipasi dalam proses perencanaan pelaksanaan perubahan (Shea, Jacobs, Esserman, Bruce, \& Weiner, 2014). Oleh karena itu, banyak peneliti yang telah menemukan kesiapan individu untuk berubah merupakan faktor penting dalam upaya perubahan yang berhasil (Bernerth, 2004).

Readiness for change pada konteks individu dalam organisasi berarti individu yang secara mental maupun fisik dapat memersiapkan diri untuk menghadapi perubahan (Madsen, dalam Nugraheni, 2012). Faktor yang dapat mempengaruhi kesiapan individu untuk berubah, dapat dikelompokkan menjadi dua yaitu, faktor individu dan organisasi (Lizar, Mangundjaya, \& Rachmawan, 2015).

Salah satu faktor dari individu yaitu modal psikologis. Modal psikologis adalah keadaan perkembangan positif individu yang ditandai dengan memiliki keyakinan (self efficacy), membuat atribusi positif (optimism), mengarahkan tujuan (hope), dan bertahan (resiliency) dalam mencapai keberhasilan (Luthans dkk. 2007).

Sedangkan, salah satu faktor organisasi yaitu persepsi dukungan organisasi. Eisenberger dkk. (1986) mendefinisikan perceived organizational support (POS) mengacu pada persepsi pegawai mengenai sejauh mana organisasi peduli dengan kesejahteraan mereka.

Pada penelitian kali ini, peneliti berfokus pada perubahan organisasi yang secara spesifik peneliti temukan masalahnya di salah satu kementerian. Fenomena yang berkaitan dengan perubahan organisasi, baru-baru ini sedang terjadi di salah satu Kementerian yang ada di Indonesia, yaitu pada Kementerian Kelautan dan Perikanan (KKP). Perubahan organisasi yang terjadi pada KKP yaitu adanya restrukturisasi dengan melakukan penggabungan pada struktur organisasinya.

Tujuan dilakukannya penggabungan pada struktur organisasi ini yaitu untuk efisiensi dan optimalisasi pelaksanaan tugas dan optimalisasi penggunaan anggaran. Dampaknya, kini mereka dituntut untuk lebih intensif lagi kinerja kerjanya, karena yang awalnya hanya mengawasi 1 bidang saja kini menjadi lebih dari 1 bidang.

Pada tahap pertama ini, KKP baru menggabungkan Badan Riset dengan Badan Pengembangan SDM dan Pemberdayaan Masyarakat Kelautan dan Perikanan, menjadi Badan Riset dan SDM Kelautan dan Perikanan. Struktur organisasi yang paling terlihat penggabungannya ada pada Bidang Pelatihan dan Bidang Penyuluhan, yang awalnya berdiri sendiri, kini 2 Bidang tersebut digabung menjadi Pusat Pelatihan 
dan Penyuluhan Kelautan dan Perikanan (PPPKP) yang berada pada Badan Riset dan SDM Kelautan dan Perikanan. Pusat Pelatihan dan Penyuluhan tersebut terdiri dari, Bidang Perencanaan dan Evaluasi, Bidang Pelatihan, Bidang Penyuluhan, dan Bidang Tata Usaha. Adanya penggabungan tersebut, menjadikan para pegawainya semakin banyak dalam satu bidang.

Peneliti menemukan sejumlah informasi bahwa setelah dilakukannya perubahan pada struktur organisasi, banyak menimbulkan pro dan kontra dari para pegawai, antara lain beberapa pegawai melakukan protes, menerima perubahan dengan terpaksa, bahkan bekerja dengan tidak maksimal. Oleh karena itu, guna mewujudkan keberhasilan perubahan yang sedang berlangsung, penting sekali peran pegawai yang ada dalam Pusat Pelatihan dan Penyuluhan Kelautan dan Perikanan Kementerian KP untuk ikut andil dan mendukung perubahan tersebut. Peran para pegawai tersebut dapat dilihat dari siap atau tidaknya pegawai yang ada disana untuk menghadapi perubahan yang sedang berlangsung.

Berdasarkan berbagai penjelasan di atas penelitian ini bertujuan untuk menguji pengaruh modal psikologis dan persepsi dukungan organisasi terhadap kesiapan individu untuk berubah pada pegawai yang ada di Pusat Pelatihan dan Penyuluhan Kelautan dan Perikanan KKP.

\section{Perubahan Organisasi}

Perubahan yang efektif memerlukan penguatan perilaku, sikap, dan praktik organisasi (Kreitner \& Kinicki, 2004). Perubahan organisasi juga dapat terdiri dari proses penyusunan kembali struktur yang ada dan menciptakan struktur baru (Hutchison dalam Weeks, Roberts, Chonko, \& Jones, 2004).

\section{Kesiapan Individu untuk Berubah}

Individu yang siap untuk berubah berarti dapat menunjukkan sikap proaktif dan sikap positif, yang dapat diterjemahkan ke dalam kemauan untuk mendukung dan percaya diri dalam keberhasilan dari suatu perubahan. Persiapan dari tindakan atau dukungan ini bergantung pada apakah manfaat perubahan yang dirasakan lebih besar daripada resiko yang diantisipasi untuk perubahan (Vakola, 2013).

Cunningham dkk. (2002) berpendapat bahwa kesiapan individu untuk berubah adalah kesiapan yang melibatkan kebutuhan untuk menunjukkan perubahan, dimana seseorang merasa mampu mencapai perubahan (self-efficacy) dan memiliki kesempatan untuk berpartisipasi dalam proses perubahan.

Kesiapan indvidu untuk berubah didefinisikan sejauhmana pegawai secara mental, psikologis, atau fisik, siap atau prima untuk berpartisipasi dalam kegiatan pengembangan organisasi (Hanpachern, dalam Nugraheni, 2012). Tiga dimensi yang ada dalam kesiapan individu untuk berubah menurut Hanpachern (dalam Nugraheni, 2012) yaitu sikap negatif dari pegawai terhadap perubahan (resisting), partisipasi pegawai dalam proses perubahan (participating), dan seberapa jauh pegawai ingin menerapkan proses perubahan (promoting).

\section{Modal Psikologis}

Salah satu aliran dalam Psikologi yang berfokus pada Psikologi Positif dalam organisasi dan tempat kerja, memerluas alirannya ke dalam lingkungan kerja yang penekanannya pada Positive Organizational Behavior (POB) atau perilaku organisasi positif. POB difokuskan pada dampak kinerja untuk meneliti variabel psikologi positif yang ada di organisasi. Hingga pada akhirnya muncul konstruk psikologi positif baru yang ada di organisasi, yaitu psychological capital atau modal psikologis.

Modal psikologis adalah keadaan perkembangan positif individu yang ditandai dengan memiliki keyakinan (self efficacy), membuat atribusi positif (optimism), mengarahkan tujuan (hope), dan bertahan (resiliency) dalam mencapai keberhasilan (Luthans dkk. 2007). 
Self efficacy berarti seorang individu memiliki keyakinan ketika menerima tugas atau pekerjaan yang menantang, dan akan berupaya memberikan usaha untuk sukses dalam tugas atau pekerjaan tersebut. Optimism yaitu membuat atribusi positif terkait sukses dimasa sekarang dan dimasa depan serta tekun ke arah tujuan.

Hope yaitu mengarahkan jalan untuk tujuan yang berhasil. Kapasitas positif terakhir yaitu resiliency berarti ketika individu dilanda masalah atau kesulitan maka akan mampu bertahan untuk mencapai keberhasilannya. Dalam hal ini karakteristik yang membangun modal psikologis saling mempengaruhi satu sama lain, maka dari itu konstruk ini lebih baik diukur sebagai satu kesatuan. Selain itu, modal psikologis menjadi tidak memadai apabila hanya menganalisis satu atau beberapa karakteristik dari konstruk ini.

\section{Persepsi Dukungan Organisasi}

Dalam pandangan teori pertukaran sosial, persepsi dukungan organisasi yang ada dalam organisasi dapat menciptakan kewajiban bagi pegawai untuk peduli terhadap kesejahteraan organisasi serta membantu pencapaian tujuan organisasi. Eisenberger, Stinglhamber, Vandenberghe,

Sucharski, dan Rhoades (2002) menjelaskan bahwa hubungan antara pegawai dengan organisasi adalah hubungan timbal balik sosial (social exchange relationship). Timbal balik yang dilakukan oleh organisasi maupun pegawai yaitu perlakuan baik yang diterima salah satu pihak harus dibalas, sehingga dapat menghasilkan keuntungan bagi kedua belah pihak.

Persepsi dukungan organisasi yaitu sejauhmana pegawai percaya bahwa organisasi menghargai kontribusi pegawai dan peduli terhadap kesejahteraan dirinya (Eseinberger dkk., 1986). Persepsi dukungan organisasi juga mengacu pada persepsi pegawai mengenai sejauh mana organisasi menilai kontribusi, memberi dukungan, dan peduli pada kesejahteraan pegawai (Eisenberger dkk., 2002).

Berdasarkan teori dukungan organisasi (Eisenberger dkk., 2002) terdapat tiga kategori utama dari perlakuan yang dirasakan oleh pegawai yang memiliki hubungan dengan persepsi dukungan organisasi yaitu, keadilan (fairnes), dukungan supervisor (supervisory support), serta penghargaan organisasi dan kondisi kerja (organizational reward and job conditions).

Hipotesis penelitian ini adalah: Terdapat pengaruh modal psikologis dan persepsi dukungan organisasi terhadap kesiapan individu untuk berubah pada pegawai di Pusat Pelatihan dan Penyuluhan Kelautan dan Perikanan di KKP.

\section{Metode Penelitian}

Penelitian ini menggunakan pendekatan kuantitatif. Metode yang digunakan adalah non-eksperimental yaitu korelasional. Dengan menggunakan teknik sampling berupa disproportionate random sampling, didapatkan 62 pegawai yang bekerja di Pusat Pelatihan dan Penyuluhan Kelautan dan Perikanan Kementerian KP. Subjek terdiri dari $36(58.1 \%)$ laki-laki dan 26 (41.9\%) perempuan, berusia dari 24-55 tahun. Pendidikan terakhir subjek paling rendah adalah SMA dan jenjang pendidikan tertinggi adalah S3. Pada umumnya, subjek yang ada memiliki jabatan sebagai staf atau pelaksana. Lama bekerja subjek mulai dari 1-36 tahun.

Alat ukur yang digunakan dalam penelitian ini terdiri dari 3 skala. Dalam tahap uji coba alat ukur, uji reliabilitas dilakukan dengan menggunakan Rasch Model dengan bantuan Winstep 7.3. Menurut Rasch Model ada 3 macam reliabilitas yang dapat diukur yaitu person reliability, item reliability, dan alpha cronbach (Sumintono \& Widhiarso, 2014). Ketiga skala termasuk dalam kategori reliabilitas baik.

Skala kesiapan individu untuk berubah (12 item) dari Hanpachern (1997) yang 
telah diadaptasi ke dalam bahasa Indonesia oleh Nugraheni (2012). Hasil uji reliabilitas yang dilakukan oleh peneliti menghasilkan nilai person reliability .71, nilai alpha cronbach .75, dan nilai item reliability .91 . Skala modal psikologis (20 item) dari Luthans dkk. (2007), dengan nilai person reliability .80, nilai alpha cronbach .87, dan nilai item reliability .81 . Skala persepsi dukungan organisasi (14 item) dari Eisenberger dkk. (1986), dengan nilai person reliability .85 , nilai alpha cronbach .88 , dan nilai item reliability .74 .

Analisis data yang dilakukan dalam penelitian ini adalah uji asumsi klasik dan uji hipotesis. Uji asumsi klasik terdiri dari uji normalitas, uji multikolinearitas dan uji heteroskedastisitas. Sedangkan uji hipotesis dalam penelitian ini menggunakan regresi linear berganda.

\section{Hasil Penelitian dan Pembahasan Hasil Penelitian}

Berdasarkan norma kategorisasi data hasil penelitian, diketahui bahwa kesiapan individu untuk berubah pada pegawai di Pusat Pelatihan dan Penyuluhan Kementerian Kelautan dan Perikanan, berada di rentang sedang yaitu sebanyak 32 orang (51.6\%). Lalu, untuk gambaran modal psikologis yang dimiliki juga berada pada rentang kategori sedang yaitu 30 orang (48.4\%). Terakhir, gambaran persepsi dukungan organisasi juga berada pada kategori sedang yaitu sebanyak 22 orang (35.5\%). Sebelum melakukan uji hipotesis, peneliti melakukan uji asumsi klasik terlebih dahulu yang terdiri dari uji normalitas, uji multikolinearitas, dan uji heteroskedastisitas.

Uji normalitas dengan One Sample Kolmogorov-Smirnov, menunjukkan bahwa distribusi data penelitian bersifat normal dengan nilai $\mathrm{p}=.200(\mathrm{p}>.05)$.

Hasil uji multikolinearitas menunjukkan, tidak terjadi masalah multikolinearitas pada model regresi, yang berarti tidak terjadi saling hubungan antar variabel bebas. Hasil ini didapat dengan melihat nilai tolerance sebesar .881 (>.1) dan nilai VIF sebesar $1.135 \quad(<10)$ pada variabel modal psikologis dan persepsi dukungan organisasi.

Hasil uji heteroskedastisitas menunjukkan bahwa tidak terjadi masalah heteroskedastisitas dengan nilai $\mathrm{p}=.975$ (>.05) untuk modal psikologis dan $\mathrm{p}=.074$ (>.05) untuk persepsi dukungan individu. Dari hasil uji asumsi klasik, maka model penelitian ini dapat dinyatakan memenuhi persyaratan untuk uji regresi.

Hasil analisis regresi memperoleh nilai $\mathrm{R}$ Square sebesar .271. Artinya 27.1\% variabel kesiapan individu untuk berubah dipengaruhi oleh modal psikologis dan persepsi dukungan organisasi. Sedangkan $72.9 \%$ dipengaruhi oleh variabel-variabel lain di luar penelitian.

\section{Uji F}

Berdasarkan hasil pengujian, signifikansi $\mathrm{F}$ adalah .000. Nilai signifikansi lebih kecil dari .05 tersebut menandakan bahwa modal psikologis dan persepsi dukungan organisasi berpengaruh secara signifikan terhadap kesiapan individu untuk berubah, hal ini berarti hipotesis pada penelitian ini diterima.

\section{Uji t}

Hasil yang diperoleh yaitu, nilai koefisien regresi variabel modal psikologis adalah .220 dengan t-value 3.299 (sig. .002), artinya variabel modal psikologis memengaruhi kesiapan individu untuk berubah secara signifikan.

Sedangkan, hasil yang diperoleh pada nilai koefisien regresi variabel persepsi dukungan organisasi adalah .111 dengan $t$ value 1.987 (sig. .052), artinya variabel persepsi dukungan organisasi tidak mempengaruhi kesiapan individu untuk berubah.

\section{Hasil Uji Besaran Varian Proporsi Tiap Independent Variabel (IV).}

Variabel modal psikologis memberikan sumbangan atau pengaruh sebesar $22.3 \%$ terhadap kesiapan individu untuk berubah dengan nilai $\mathrm{F}$ Change hitung sebesar 
17.182 dengan sig. F Change .000. Artinya dapat dinyatakan bahwa sumbangan modal psikologis terhadap kesiapan individu untuk berubah signifikan.

Sedangkan, pada variabel persepsi dukungan organisasi memberikan sumbangan atau pengaruh sebesar $4.9 \%$ terhadap kesiapan individu untuk berubah dengan nilai F Change hitung sebesar 3.949 dengan sig. F Change .053. Artinya dapat dinyatakan sumbangan persepsi dukungan organisasi terhadap kesiapan individu untuk berubah tidak signifikan.

\section{Pembahasan}

Hasil analisis statistik dalam penelitian ini menunjukkan bahwa modal psikologis dan persepsi dukungan organisasi secara bersama-sama memiliki pengaruh terhadap kesiapan individu untuk berubah, dengan nilai signifikan sebesar .000. Hal ini mengindikasikan bahwa, kondisi perkembangan positif individu serta didukung dengan keyakinan pegawai mengenai kepedulian organisasi terhadap kesejahteraan individu, berperan terhadap kesiapan individu untuk berubah.

Artinya semakin tinggi modal psikologis individu dan persepsi pegawai mengenai dukungan organisasi, akan semakin meningkatkan kesiapan inidvidu untuk menghadapi perubahan. Peneliti mengidentifikasikan pengaruh dari modal psikologis dan persepsi dukungan organisasi terhadap kesiapan individu untuk berubah hanya sebesar $27.1 \%$ (berdasarkan nilai $\mathrm{R}^{2}$ kedua variabel bebas terhadap variabel tergantung) disebabkan, dari ketiga variabel baik itu modal psikologis, persepsi dukungan organisasi, dan kesiapan individu untuk berubah, gambarannya berada pada kategori tingkat norma sedang. Oleh karena itu, nilai proporsi varians IV terhadap DV tidak begitu besar.

Secara keseluruhan pegawai yang berada di Pusat Pelatihan dan Penyuluhan Kementerian dan Kelautan sudah cukup menunjukkan kesiapan untuk menghadapi perubahan yang ada. Hal ini ditunjukkan dengan nilai norma yang berada pada kategori sedang, yakni dengan persentase $56.6 \%$. Akan tetapi, masih ada juga dari beberapa pegawai yang menunjukkan kesiapan yang rendah, bahkan sangat rendah. Oleh karena itu, kesiapan para pegawai dalam menjalani perubahan masih perlu ditingkatkan, dengan memiliki kondisi perkembangan yang positif dan persepsi terhadap dukungan organisasi yang baik.

Hasil ini didukung oleh penelitian Munawaroh dan Meiyanto (2017), bahwa pegawai yang memersepsikan secara positif dukungan dari organisasinya, akan membuat pegawai tersebut memiliki harapan dan optimisme terhadap organisasi. Harapan, keyakinan diri, optimisme dan resiliensi itu merupakan bagian dari modal psikologis yang berperan terhadap kesiapan berubah bagi individu. Dukungan dari organisasi dan manajerial dapat berupa komunikasi yang efektif tentang perubahan, pelatihan, pembinaan serta konseling (Lizar dkk. 2015).

Selain itu, para pegawai yang ada di Pusat Pelatihan dan Penyuluhan Kelautan dan Perikanan juga sudah cukup menunjukkan kondisi perkembangan individu yang positif atau modal psikologis. Hal ini ditunjukkan dengan nilai norma yang berada pada kategori sedang, yakni dengan persentase $48.4 \%$. Hal yang sama juga terjadi pada persepsi pegawai mengenai dukungan organisasi yang ada. Para pegawainya menunjukkan bahwa, persepsi mereka mengenai dukungan organisasinya sudah cukup. Hal ini ditunjukkan dengan nilai norma yang berada pada kategori sedang, yakni dengan persentase $35.5 \%$.

Jika dilihat secara terpisah pengaruhnya terhadap kesiapan individu untuk berubah, hanya modal psikologis saja yang memiliki pengaruh yang signifikan $(\mathrm{p}<.05)$ terhadap kesiapan individu untuk berubah. Temuan ini sejalan dengan hasil penelitian Mangundjaya (2012), Ming-Chu dan Meng-Hsiu (2015), Lizar dkk. (2015) dan Jabbarian dan Chegini (2017), yang menunjukkan bahwa modal psikologis memiliki 
pengaruh yang signifikan terhadap kesiapan individu untuk berubah.

Peneliti menemukan bahwa, ketika modal psikologis yang dimiliki pegawai sudah tinggi, maka pegawai akan siap untuk berubah. Hal ini berarti jika dikaitkan dengan empat aspek modal psikologis yaitu ketika ada tugas atau pekerjaan yang baru dalam perubahan, pegawai akan menerimanya dengan senang hati, serta akan memberikan usaha untuk sukses dalam pekerjaan tersebut. Pegawai juga akan menganggap bahwa, pekerjaan baru yang individu terima sebagai pekerjaan yang menantang. Selain itu, nantinya pegawai akan membuat keputusan yang positif dalam tugas yang baru terkait sukses di masa sekarang dan masa depan. Pegawai pun akan selalu mengarahkan jalan untuk tujuan yang berhasil, dan ketika dihadapkan pada masalah atau kesulitan, inidvidu dapat tetap bertahan untuk mencapai keberhasilan. Selanjutnya, harus pula didukung juga oleh dukungan dari organisasi yang efektif mengenai perubahan.

Sedangkan, persepsi dukungan organisasi tidak memiliki pengaruh yang signifikan ( $p>.05)$ terhadap kesiapan individu untuk berubah. Artinya, dalam konteks penelitian ini, persepsi yang dirasakan pegawai mengenai dukungan organisasi, tidak akan memengaruhi kesiapan pegawai untuk berubah di Pusat Pelatihan dan Penyuluhan KKP. Hasil ini berbeda dengan hasil penelitian Ming-Chu dan Meng-Hsiu (2015), Dharmawan dan Nurtjahjanti, (2017), dan juga hasil penelitian Jabbarian dan Chegini (2017) terhadap staf resmi kotamadya di Provinsi Guilan, yang menunjukkan adanya hubungan yang positif antara kesiapan individu untuk berubah dengan persepsi dukungan organisasi.

Walaupun pada banyak penelitian diketahui bahwa variabel persepsi dukungan organisasi mampu meningkatkan pegawai untuk merasa berkewajiban membantu organisasi mencapai tujuannya, ternyata diperoleh hasil yang berbeda pada penelitian ini. Peneliti memaknai hasil penelitian ini dari dua sisi. Pertama, hasil penelitian ini memperlihatkan bahwa apabila hanya variabel persepsi dukungan organisasi, yang merupakan faktor organisasi yang menjadi variabel bebas, maka belum mampu memberikan pengaruh terhadap kesiapan individu untuk berubah. Kedua, ketika menjalankan penelitian, peneliti mendapatkan tanggapan dari beberapa responden penelitian yang merasa bahwa kuesioner mengenai persepsi dukungan organisasi kurang sesuai di kalangan instansi pemerintahan. Meski tanggapan hanya diutarakan oleh sebagian kecil responden, peneliti merasa kondisi menarik untuk menjadi pertimbangan terutama untuk peneliti selanjutnya. Fakta ini baru peneliti temui di akhir proses penelitian dimana di awal penelitian peneliti berasumsi bahwa persepsi dukungan organisasi layak diteliti dalam konteks pemerintahan.

Setelah mendapatkan temuan tersebut, peneliti mencoba menyampaikan alasan terkait hal itu. Di instansi pemerintahan, kebijakan organisasi mengenai pengembangan maupun perampingan organisasi dibuat berdasarkan top-down, bukan bottomup. Top-down merupakan kebijakan dari pemerintah yang dilakukan berdasarkan kebutuhan dan kondisi keuangan negara, yang tidak melibatkan dan memerlukan masukan dari anggota organisasi. Ketika suatu kebijakan telah ditetapkan, para pegawai memang diwajibkan untuk mengikuti kebijakan yang ada, sehingga mau tidak mau para pegawai harus mengikuti kebijakan tersebut. Artinya, dalam penelitian ini faktor organisasi saja tidak mampu memengaruhi kesiapan dari para pegawai untuk berubah, maka dari itu penting pula didukung oleh faktor dari diri individu itu sendiri, seperti modal psikologis, agar nantinya tujuan dari perubahan dapat tercapai dengan lebih baik.

Keterbatasan dalam penelitian ini adalah jumlah sampel berdasarkan jabatan yang masih belum proporsional pembagiannya. Hal ini disebabkan banyak dari pegawai yang sedang mengikuti pelatihan, 
sehingga tidak berada di tempat ketika pengambilan data berlangsung.

\section{Simpulan dan Saran}

Berdasarkan hasil analisis data dan uji hipotesis yang telah dilakukan peneliti, dapat disimpulkan bahwa terdapat pengaruh signifikan dari modal psikologis dan persepsi dukungan organisasi secara bersama-sama terhadap kesiapan individu untuk berubah pada pegawai di Kementerian KKP. Berdasarkan uji pengaruh untuk masing-masing variabel bebas didapatkan hasil bahwa, hanya variabel modal psikologis yang memengaruhi kesiapan untuk berubah secara signifikan. Sedangkan, untuk variabel persepsi dukungan organisasi tidak memberikan pengaruh terhadap kesiapan individu untuk berubah.

\section{Saran Metodologis}

Setelah mengkaji kembali penelitian ini, peneliti menyadari bahwa masih banyak kekurangan dalam penelitian ini. Untuk itu, peneliti menuliskan beberapa saran untuk perbaikan dalam penelitian lebih lanjut, yaitu: pertama, bagi peneliti yang ingin mengembangkan penelitian terkait dengan kesiapan individu untuk berubah terutama dalam konteks Pegawai Negeri Sipil (PNS), dapat mengganti faktor dari organisasi selain variabel persepsi dukungan organisasi, dan menyesuaikan variabel yang lebih sesuai dengan karakteristik PNS. Kedua, dapat melakukan survei atau wawancara singkat kepada beberapa pegawai mengenai hal-hal apa saja yang kiranya dapat memengaruhi inidividu untuk lebih siap menghadapi perubahan. Dengan demikian peneliti selanjutnya bisa menduga kira-kira variabel apa saja yang sekiranya dapat memengaruhi kesiapan individu untuk berubah. Ketiga, peneliti berikutnya, yang ingin melakukan penelitian mengenai kesiapan individu untuk berubah, khususnya pada konteks PNS serta memiliki karakteristik sampel yang berstrata, dapat menggunakan teknik pengambilan sampel stratified sampling berdasarkan masa kerja atau tingkat jabatan pegawai.

\section{Saran Praktis}

Saran praktis yang dapat peneliti berikan terkait dengan penelitian ini, yaitu: pertama, untuk para pegawai, dapat terus meningkatkan kemampuan diri, optimisme, harapan serta ketahanan terkait dengan pekerjaan yang sedang dihadapi saat ini, terutama setelah perubahan terjadi. Kedua, untuk instansi dapat meningkatkan dukungan yang diberikan kepada pegawai, seperti komunikasi yang efektif tentang perubahan, pelatihan, serta pembinaan, agar pegawai dapat terus memberikan hasil kerja yang maksimal dan memiliki kualitas tinggi.

\section{Daftar Pustaka}

Armenakis, A. A., Harris, S. G., \& Mossholder, K. W. (1993). Creating readiness for organizational change. Human Relations, 46(6), 681-703. doi.org/10.1177/00187267930460060 1

Bernerth, J. (2004). Expanding our understanding of the change message. Human Resource Development Review, 3(1), 36-52. doi.org/10.1177/1534484303261230

Cummings, T. G. \& Worley, C. G. (2008). Organization change and development. 9th edition. USA: South Western Cengage Learning.

Cunningham, C. E., Woodward, C. A., Shannon, H. S., MacIntosh, J., Lendrum, B., Rosenbloom, D., \& Brown, J. (2002). Readiness for organizational change: A longitudinal study of workplace, psychological and behavioural correlates. Journal of Occupational and Organizational Psychology, 75(4), 377-392. doi.org/10.1348/09631790232111963 7 
Desiana, A. (2014). Reformasi birokrasi pemerintahan daerah menuju good gocevermacne. JMP, 1 (1).

Dharmawan, D. C., \& Nurtjahjanti, H. (2017). Hubungan antara perceived organizational support dan kesiapan untuk berubah pada karyawan PT. KAI. Jurnal Empati, 6(1), 115-119.

Eby, L. T., Adams, D. M., Russell, J. E. A., \& Gaby, S. H. (2000). Perceptions of organizational readiness for change: Factors related to employees' reactions to the implementation of team-based selling. Human Relations, 53(3), 419-442. doi.org/10.1177/0018726700533006

Eisenberger, R., Huntington, R., Hutchison, S., \& Sowa, D. (1986). Perceived organizational support. Journal of Applied Psychology, 71, 500-507.

Eisenberger, R., Stinglhamber, F., Vandenberghe, C., Sucharski, I. L., \& Rhoades, L. (2002). Perceived supervisor support: Contributions to perceived organizational support and employee retention. Journal of Applied Psychology, 87(3), 565-573. doi.org/10.1037/0021-9010.87.3.565

Jabbarian, J., \& Chegini, M. G. (2017). The effect of perceived organizational support on employee resistance to change: A study on Guilan Municipal staff. Journal of History Culture and Art Research, 5(4), 642. doi.org/10.7596/taksad.v5i4.627

Kreitner, R \& Kinicki, A. (2004). Organizational behavior. $6^{\text {th }}$ edition. America, New York: McGrawHill/Irwin.

Lizar, A. A., Mangundjaya, W. L. ., \& Rachmawan, A. (2015). The role of psychological capital and psychological empowerment on individual readiness for change. The Journal of Developing Areas, 49(5), 343-352.

doi.org/10.1353/jda.2015.0063

Luthans, F., Youssef, C. M., \& Avolio, B. J. (2007). Psychological capital developing: The human competitive edge. New York: Oxford University Press, Inc.

Mangundjaya, W. L. H. (2012). Are organizational commitment and employee engagement important in achieving individual readiness for change. Humanitas, 8(2), 1-8. doi.org/10.26555/humanitas.v9i2.344

Mangundjaya, W. L. H. (2014). Is workplace well-being important to individual readiness for change?. Faculty of Psychology, Universitas Indonesia.

Ming-Chu, Y., \& Meng-Hsiu, L. (2015). Unlocking the black box: Exploring the link between perceive organizational support and resistance to change. Asia Pacific Management Review, 20(3), 177-183. doi.org/10.1016/j.apmrv.2014.10.003

Munawaroh, L., \& Meiyanto, I. S. (2017). Peranan psychological capital terhadap kesiapan individu untuk berubah yang dimoderatori oleh persepsi dukungan organisasi. Jurnal Psikologi, $\quad 44(3), \quad 185$. doi.org/10.22146/jpsi.25381

Nugraheni, A. (2012). Pelatihan self efficacy untuk meningkatkan kesiapan dalam menghadapi perubahan pada pegawai PT PLN (persero) pusdiklat. (Tesis tidak diterbitkan), Fakultas Psikologi Program Studi Ilmu Psikologi Peminatan Terapan Psikologi SDM.

Pramadani, A. B. (2012). Hubungan antara komitmen organisasi dengan kesiapan untuk berubah pada karyawan divisi enterprise service (DES) telkom ketintang Surabaya. Jurnal Psikologi Industri Dan Organisasi, 1(03), 112119.

Robbins, S., \& Judge, A. T. (2013). Organizational behavior. $15^{\text {th }}$ edition. Essex: Pearson Education Limited.

Shea, C. M., Jacobs, S. R., Esserman, D. A., Bruce, K., \& Weiner, B. J. (2014). Organizational readiness for 
implementing change: A psychometric assessment of a new measure. Implementation Science, 9(1), 1-15. doi.org/10.1186/1748-5908-9-7

Sumintono, B., \& Widhiarso, W. (2014). Aplikasi model rasch untuk penelitian ilmu-ilmu sosial. Cimahi: Trim Komunikata Publishing House.

Vakola, M. (2013). Multilevel readiness to organizational change: A conceptual approach. Journal of Change Management, 13(10), 37-41. doi.org/10.1080/14697017.2013.7684 36

Weeks, W. A., Roberts, J., Chonko, L. B., \& Jones, E. (2004). Organizational readiness for change, individual fear of change, and sales manager performance: An empirical investigation. Journal of Personal Selling and Sales Management, 24(1), 7-17.

doi.org/10.1080/08853134.2004.1074

9012 